\title{
Peningkatan Produksi Asi Ibu Menyusui Pasca Melalui Pemberian Pijat Oksitosin dan Terapi Musik Klasik (Mozart) Wilayah Kerja Puskesmas Kradenan 2
}

\author{
Maryatun, Dyah Kusuma Wardhani, Eska Dwi P \\ STIKES 'Aisyiyah Surakarta \\ Tun_Marya@yahoo.com \\ Doi : https://doi.org/10.30787/gaster.v17i2.400 \\ Received: April 2019 | Revised: Mei 2019 | Accepted: July 2019
}

\begin{abstract}
ABSTRAK
Latar belakang: Air susu ibu adalah makanan terbaik bagi bayi. Kehidupan awal seorang bayi akan rentan dan beresiko terhadap masalah ancaman kesakitan dan kematian. Seorang Ibu terutama pada primigravida pada awal persalinan akan mengalami kesulitan dalam pengeluaran ASI. Tujuan: mengetahui perbedaan pemberian pijat oksitosin dan terapi musik klasik (mozart) terhadap jumlah produksi ASI. Metode: JenisPenelitian kuantitatif komperatif. Populasi ibu menyusui yang melahirkan. Sampel sebanyak 34 responden yang dibagi dalam dua kelompok yang menggunakan metode non probability sampling. Instrumen penelitian adalah observasi,. Hasil: Hasil uji Mann Whitney Test produksi ASI kelompok Pijat oksitosin dan kelompok Terapi musik klasik diperoleh nilai signifikansi (p-value) 0,011, rata-rata selisih pada kelompok pijat oksitosin lebih tinggi dari pada selisih produksi ASI pada kelompok terapi musik yaitu 65,91 > 53,41 Simpulan: Terdapat perbedaan antar pijat oksitosin dan musik klasik. Produksi ASI lebih banyak pijat oksitosin bila dibandingkan musik klasik.
\end{abstract}

Kata kunci: produksi ASI; ibu post partum; pijat oksitosin; musik klasik (Mozart)

\section{ABSTRACT}

Background: A mother especially in primigravida at the beginning childbirth expenditure will experienced difficulty in place.The knows the difference: the massage oksitosin and therapeutic classical music to the production Objective: know the difference of giving of oxytocin massage and classical music therapy (mozart) to the amount of milk production at Method: This research includes comperative quantitative research. The population of breastfeeding mothers who gave birth. Samples of 34 respondents were divided into two groups using non-probability sampling method. The research instrument was observation. Research Result: Result of Mann Whitney Test of production difference of ASI of ASI production group Massage of oxytocin and group of classical music therapy obtained with value of significance (p-value) 0,011. The value of test significance (p-value) lower than $0.05(0.011<0.05)$, where the average difference in the oxytocin massage group was higher than the difference in milk production in the music therapy

188 Peningkatan Produksi Asi Ibu Menyusui Pasca .... 
group that is 65,91> 53,41. Conclusion: There is a different between oxytocin massage and mozart classical music. More breast milk production in the oxytocin massage when compered to classical music.

Keyword: milk production, post partum mother, oxytocin massage, classical music (Mozart)

\section{PENDAHULUAN}

Seorang ibu pasca melahirkan mempunyai kecemasan yang meningkat sebagai respon adaptasi fungsi fisiologis. Kecemasan yang berlebihan dapat mengakibatkan terhambatnya pembentukan hormone relaksasi yang dapat memicu pengeluaran oksitosin. Memperbanyak produksi ASI dapat dilakukan juga dengan teknik pijat Oksitosin. Prosedur Pijat oksitosin merupakan pemijatan yang bertujuan untuk merangsang hormone oksitosin dan prolaktin setelah ibu melahirkan, untuk memperlancar produksi ASI (Indriyani, 2016).

ASI merupakan cairan yang sangat penting untuk bayi karena memiliki kandungan zat antibodi dapat menjaga bayi dari infeksi. Namun ternyata tidak semua ibu postpartum dapat memproduksi ASI dengan jumlah yang cukup bagi bayinya. Upaya-upaya untuk meningkatkan produksi ASI pada ibu postpartum adalah meningkatkan hormon oksitosin dan bagaimana menekan timbulnya kecemasan pada ibu post partum.
Faktor yang dapat mempengaruhi produksi ASI itu berasal dari hormonal (hormon prolaktin dan hormon oksitosin), kurangnya pengetahuan $\mathrm{ibu}$, rasa percaya diri yang kurang dan kurangnya dukungan suami serta keluarga. Gangguan proses pemberian ASI juga dipengaruhi oleh suasana hati ibu yang rileks dan santai, apabila suasana hati ibu tidak rileks dan santai akan menyebabkan ASI sulit untuk keluar dan juga nutrisi ibu saat menyusui juga harus terpenuhi (Sulistyoningsih, 2011).

Penelitian Dewi (2016) menyebutkan bahwa peningkatan produksi ASI juga bisa dengan terapi musik klasik (Mozart) yang bertujuan sebagai terapi relaksasi. Mendengarkan irama musik dapat mempengaruhi sistem pada otak yang akan menekan fungsi poros hipotalamus, hipofisis dan kelenjar adrenal untuk menghambat pengeluaran hormon stres sehingga produksi hormon oksitosin dan prolaktin lebih maksimal. Tujuan dalam penelitian ini mengetahui perbedaan Pemberian Pijat Oksitosin Dan Terapi Musik Klasik (Mozart) Terhadap Jumlah Produksi ASI Pada Ibu Menyusui ?’. 


\section{BAHAN DAN METODE}

Jenis Penelitian kuantitatif komperatif dengan Metode rancangan metode Quasi Eksperiment design dengan rancangan Two Group pre-test-post-test.Populasi dari penelitian ini adalah ibu yang menyusui Sampel penelitian non probability sampling dengan metode purposive sampling sebanyak 34 responden yaitu 15 kelompok pijat oksitosin dan 15 kelompok terapi musik klasik (mozart) .Penelitian menggunkan analisa univariat, bivariat dengan uji Wilcoxon untuk membedakan pretest-posttest masingmasing kelompok dan uji Man Whitney untuk membedakan antar kelompok.

\section{HASIL DAN PEMBAHASAN}

Tabel 1. Jumlah produksi ASI pada ibu menyusui sebelum dilakukan intervensi terapi pijat oksitosin

\begin{tabular}{lcc}
\hline \multirow{2}{*}{ Kategori } & \multicolumn{2}{c}{ Terapi pijat oksitosin } \\
& Frekuensi & Persentase (\%) \\
\hline Sedikit & 15 & 88 \\
Normal & 2 & 12 \\
Banyak & 0 & 0 \\
Total & 17 & 100 \\
\hline
\end{tabular}

Tabel 1 menunjukkan bahwa sebagian besar ibu pasca salin sebelum dilakukan perlakuan memiliki produksi ASI yang sedikit yaitu sebanyak 15 responden (88\%). Hasil penelitian serupa oleh Rahayu (2015) menunjukkan bahwa produksi ASI sebelum dilakukan terapi pijat oksitosin menunjukkan bahwa sebagian besar memiliki produksi ASI yang sedikit 15 (88\%). Penurunan produksi ASI pada hari-hari awal menyusui setelah melahirkan dapat disebabkan karena kurangnya rangsangan hormon prolaktin dan oksitosin yang sangat berperan dalam kelancaran ASI

Faktor-faktor yang mempengaruhi pada proses menyusui merupakan suatu masalah bagi seorang ibu menyusui. Hambatan saat menyusui ada beberapa yaitu kurang pengetahuan keluarga tentang pemberian ASI, ibu merasa tidak percaya diri, dan kurang dukungan baik suami maupun keluarga dan beberapa faktor yang mempengaruhi produksi ASI makanan ibu harus terjaga, hormonal, psikologi dan social (rasa percaya diri ibu, kontak langsung ibu bayi dan interaksi ibu dengan bayi) (Sulistyoningsih, 2011). Kondisi ini sejalan dengan penelitian Azizah dan Yulinda (2017) menunjukkan bahwa faktorfaktor yang mempengaruhi ASI yaitu frekuensi menyusui, berat badan bayi, usia kehamilan saat persalinan, paritas, stres dan penggunaan kontrasepsi. 
Tabel 2. Jumlah produksi ASI pada ibu menyusui sebelum dilakukan intervensi terapi musik klasik (mozart)

\begin{tabular}{lcc}
\hline Kategori & \multicolumn{2}{c}{ Terapi musik klasik (Mozart) } \\
& Frekuensi & Persentase (\%) \\
\hline Sedikit & 14 & 82 \\
Normal & 3 & 18 \\
Banyak & 0 & 0 \\
Total & 17 & 100 \\
\hline
\end{tabular}

Tabel 2 menunjukkan bahwa sebagian besar ibu pasca salin yang belum mendapatkan perlakukan terapi musik klasik (mozart) mempunyai produksi ASI sedikit sebesar 14 responden (82\%). Banyak faktor yang mempengaruhi produksi ASI seorang ibu pasca melahirkan. Penelitian Jannah, (2011) menjelaskan dalam penelitiannya bahwa faktor yang berhubungan dengan produksi ASI yang sedikit antara lain faktor psikis responden. Sebaiknya menyusui bayi secara non jadwal (on demand) karena bayi akan menentukan sendiri kebutuhannya. Isapan bayi sangat berpengaruh pada ransangan isapan produksi ASI selanjutnya.

Faktor-faktor yang berhubungan dengan produksi ASI yaitu faktor makanan dimana kebutuhan kalori ibu perhari harus terdiri dari $60-70 \%$ karbohidrat, $10-20 \%$ protein, dan 20 $30 \%$ lemak. Kalori ini didapat dari makanan yang dikonsumsi ibu dalam sehari (Nutrisi Bangsa, 2013). Hal tersebut sebagaimana dikemukakan pada penelitian Nurliawati (2010), yang menjelaskan bahwa produksi ASI dipengaruhi oleh beberapa faktor, baik yang langsung misalnya, perilaku menyusui, psikologis ibu, fisiologis ibu, ataupun yang tidak langsung misalnya, sosial kultural dan bayi, yang akan berpengaruh terhadap psikologis ibu. Faktor lain yang bisa mempengaruhi produksi ASI adalah berat badan lahir bayi. Bayi dengan berat badan lahir rendah atau kurang dari 2.500 gram mempunyai resiko dalam masalah menyusui dikarenakan oleh refleks hisap yang lemah.

Tabel 3. Jumlah produksi ASI pada ibu menyusui setelah dilakukan intervensi terapi pijat oksitosin

\begin{tabular}{lcc}
\hline \multirow{2}{*}{ Kategori } & \multicolumn{2}{c}{ Terapi pijat oksitosin } \\
& Frekuensi & Persentase (\%) \\
\hline Sedikit & 0 & 0 \\
Normal & 0 & 100 \\
Banyak & 17 & 100 \\
Total & 17 & \\
\hline
\end{tabular}

Tabel 3 menunjukkan menunjukkan Hasil penelitian menunjukkan produksi ASI setelah dilakukan intervensi pada kelompok pijat oksitosin menunjukkan semuanya dalam kategori banyak yaitu sebanyak 17 
(100\%). Tidak semua ibu postpartum langsung mengeluarkan ASI karena pengeluaran ASI merupakan suatu interaksi yang sangat komplek antara rangsangan mekanik, saraf dan bermacam-macam hormon yang berpengaruh terhadap pengeluaran oksitosin. Pengeluaran hormon oksitosin selain dipengaruh oleh isapan bayi juga dipengaruhi oleh reseptor yang terletak pada sistem duktus, bila duktus melebar atau menjadi lunak maka secara reflektoris dikeluarkan oksitosin oleh hipofise yang berperan untuk memeras air susu dari alveoli (Soetjiningsih, 2013).

Upaya untuk meningkatkan produksi ASI pada ibu melahirkan secara khusus difokuskan kepada upaya untuk meningkatkan kinerja hormon oksitosin. Efek dari pijat oksitosin itu sendiri bisa dilihat reaksinya setelah 6-12 jam pemijatan. Pijat oksitosin adalah suatu tindakan pemijatan tulang belakang mulai dari nervus ke 5-6 sampai scapula yang akan mempercepat kerja saraf parasimpatis untuk menyampaikan perintah ke otak bagian belakang sehingga oksitosin keluar (Hamranani, 2010).

Hasil penelitian Azriani dan Handayani (2016) pijat oksitosin dapat memberikan rangsangan pada payudara myoepithelial untuk berkontaksi, sehingga ASI dapat dikeluarkan dengan mudah dan lancar. Pemijatan ini dapat mestimulus sistem saraf perifer, meningkatkan rangsangan dan konduksi impuls saraf, dapat melemahkan dan meghentikan rasa sakit dan dapat memperbaiki aliran darah ke jaringan dan organ tubuh. Pemijatan ini juga dapat membuat otot menjadi tidak tegang dan memberikan efek terapeutik yang dapat menimbulkan rasa nyaman dan rileksasi sehingga ibu mengeluarkan ASInya juga lancar (Azriani dan Handayani, 2016). Menurut penelitian Sriyati dan Sari (2015) pemijatan punggung atas merupakan suatu titik akupesur yang berdampak pada untuk memperlancar ASI. Saraf yang ada dipayudara itu berasal dari tulang belakang bagian atas diantara tulang belikat. Tulang belakang pada perempuan sering mengalami ketegangan otot. Ketegangan otot ini dapat dilakukan pemijatan dengan cara memijat punggung atas supaya dapat merilekskan bahu dan dapat menstimulasi refleks let-down dan dapat membantu proses laktasi pada ibu yang sedang mengalami gangguan produksi ASI. Kesimpulan pada penelitian ini menunjukkan bahwa ada pengaruh pijat oksitosin terhadap jumlah produksi ASI pada ibu menyusui. 
Tabel 4. Jumlah produksi ASI pada ibu menyusui setelah dilakukan intervensi terapi musik klasik (Mozart)

\begin{tabular}{lcc}
\hline \multirow{2}{*}{ Kategori } & \multicolumn{2}{c}{ Terapi musik klasik (Mozart) } \\
& Frekuensi & Persentase (\%) \\
\hline Sedikit & 0 & 0 \\
Normal & 3 & 18 \\
Banyak & 14 & 82 \\
Total & 17 & 100 \\
\hline
\end{tabular}

Tabel 4 menunjukkan bahwa Hasil penelitian menunjukkan bahwa produksi ASI setelah dilakukan intervensi pada kelompok terapi musik klasik (mozart) sebagian besar adalah banyak sebanyak 14 (82\%) dan sisanya adalah normal sebanyak 3 (18\%). Setelah melahirkan, ibu merasa cemas, tidak tenang, hilang semangat, dan kurang dukungan dari suami maupun keluarga besar. Ini merupakan hal normal yang perlu diantisipasi suami maupun pihak keluarga. Ibu yang melahirkan anak pertama biasanya banyak ayah yang lebih sibuk dengan bayinya dari pada memperhatikan kebutuhan sang istri. Kondisi ini jika terusmenerus berlanjut maka ibu akan merasa bahwa perhatian suami padanya telah menipis sehingga muncul asumsi-asumsi negatif. Perasaan negatif ini akan membuat refleks oksitosin menurun dan produksi ASI pun terhambat. Meningkatkan produksi hormon oksitosin diperlukan dukungan suami selama proses menyusui (Roesli, 2010).

Upaya untuk menurunkan tingkat kecemasan ibu menyusui adalah pemberian terapi relaksasi salah satunya terapi musik klasik (Mozart). Hal ini sejalan dengan penelitian Dewi (2016) terapi musik klasik (Mozart) bertujuan sebagai terapi relaksasi karena musik dapat mempengaruhi sistem pada otak yang akan menekan fungsi poros hipotalamus, hipofisis dan kelenjar adrenal untuk menghambat pengeluaran hormon stres (epinefrin, norepinefrin, dopa, kortikosteroid) sehingga produksi hormon oksitosin dan prolaktin lebih maksimal. Musik klasik mempunyai fungsi sebagai menenangkan pikiran dan emosi, serta mengoptimalkan tempo, ritme, melodi dan harmoni yang teratur sehingga dapat menghasilkan gelombang alfa dan gelombang beta dalam gendang telinga sehingga memberikan efek ketenangan yang membuat otak siap menerima masukan baru, efek rileks, dan menidurkan. Secara umum musik menimbulkan gelombang vibrasi yang dapat menimbulkan stimulus pada gendang pendengaran. Stimulasi itu ditransmisikan pada susunan saraf pusat (limbic system) di sentral otak yang merupakan ingatan, kemudian pada 
hypothalamus atau kelenjar sentral memiliki susunan saraf pusat akan mengatur segala sesuatunya untuk mengaitkan musik dengan respon tertentu sehingga dapat meningkatkan produksi ASI. Hal ini juga sejalan dengan penelitian Manurung et al (2011) mengatakan bahwa ada pengaruh terapi musik terhadap penurunan kejadian postpartum blues yang sangat bermakna setelah dilakukan intervensi selama 3 hari diberikan terapi musik klasik, dengan demikian telah direkomendasikan sebagai terapi relaksasi selama fase childbearing yang digunakan untuk mengatasi berbagai faktor yang mempengaruhi stres pada ibu. Pelayanan kesehatan dapat melaksanakan terapi musik dengan memutar musik klasik secara kontinue dan terjadwal sehingga dapat membantu ibu postpartum menjadi rileks.

Berdasarkan adanya peningkatan jumlah ASI setelah intervensi, maka disimpulkan bahwa pemberian intervensi pada ibu post partum yaitu dengan terapi musik klasik (Mozart) dapat meningkatkan jumlah produksi ASI ibu post partum pemberian terapi musik klasik (Mozart) berdampak pada penurunan tingkat stressing pada ibu post partum sehingga kecemasan pada ibu post partum dapat diturunkan.
Tabel 5. Pre test dan Post test produksi ASI kelompok intervensi Pijat oksitosin

\begin{tabular}{lccc}
\hline Pengamatan & Rerata & Pvalue & Keputusan uji \\
\hline Pre test & 53,59 & 0,000 & $\mathrm{H}_{0}$ ditolak \\
Post test & 119,53 & & \\
\hline
\end{tabular}

Hasil uji Wilcoxon Signed Rank Test diperoleh nilai $p$-value $=0,000$, sehingga disimpulkan terdapat perbedaan produksi ASI sebelum dan sesudah pemberian pijat oksitosin, sehingga disimpulkan bahwa pemberian pijat oksitosin signifikan meningkatkan produksi ASI.

Ibu postpartum tidak langsung mengeluarkan ASI karena pengeluaran ASI merupakan suatu interaksi yang sangat komplek antara rangsangan mekanik, saraf dan bermacam-macam hormon yang berpengaruh terhadap pengeluaran oksitosin. Pengeluaran hormon oksitosin selain dipengaruh oleh isapan bayi juga dipengaruhi oleh reseptor yang terletak pada sistem duktus, bila duktus melebar atau menjadi lunak maka secara reflektoris dikeluarkan oksitosin oleh hipofise yang berperan untuk memeras air susu dari alveoli (Soetjiningsih, 2013).

Upaya pengeluaran ASI ada 2 hal yang mempengaruhi yaitu produksi dan pengeluaran. Produksi ASI dipengaruhi oleh 
hormon prolaktin sedangkan pengeluaran dipengaruhi oleh hormon oksitosin. Hormon oksitosin akan keluar melalui rangsangan ke puting susu melalui isapan mulut bayi atau melalui pijatan pada tulang belakang ibu bayi, dengan dilakukan pijatan pada tulang belakang ibu akan merasa tenang, rileks, meningkatkan ambang rasa nyeri dan mencintai bayinya, sehingga dengan begitu hormon oksitosin keluar dan ASI pun cepat keluar. Melalui pijatan atau rangsangan pada tulang belakang, neurotransmiter akan merangsang medulla oblongata langsung mengirim pesan ke hypothalamus di hypofise posterior untuk mengeluarkan oksitosin sehingga menyebabkan buah dada mengeluarkan air susunya. Pemijatan yang dilakukan di daerah tulang belakang ini juga akan merileksasi ketegangan dan menghilangkan stress dan dengan begitu hormon oksitosoin keluar dan akan membantu pengeluaran air susu ibu, dibantu dengan isapan bayi pada puting susu pada saat segera setelah bayi lahir dengan keadaan bayi normal (Guyton, 2007).

Tabel 6 Pre test dan Post test produksi ASI kelompok intervensi Terapi musik klasik (mozart)

\begin{tabular}{|l|l|l|l|}
\hline Pengamatan & Rerata & Pvalue & $\begin{array}{l}\text { Keputusan } \\
\text { uji }\end{array}$ \\
\hline $\begin{array}{l}\text { Pre test } \\
\text { Post test }\end{array}$ & $\begin{array}{l}54,35 \\
107,76\end{array}$ & 0,000 & $\mathrm{H}_{0}$ ditolak \\
\hline
\end{tabular}

Hasil uji Wilcoxon Signed Rank Test diperoleh niali $p$-value $=0,000$, sehingga disimpulkan terdapat perbedaan produksi ASI sebelum dan sesudah pemberian terapi musik klasik (mozart). Ketidakmampuan menyusui membuat ibu post partum semakin merasa tidak percaya diri dan cemas. Kondisi ini bila tidak ditangani akan membuat ibu stress dan produksi ASI akan semakin berkurang. Faktor psikis dimana masa nifas merupakan salah satu fase yang memerlukan adaptasi psikologis. Perubahan peran seorang ibu memerlukan adaptasi yang harus dijalani. Tanggung jawab bertambah dengan adanya bayi yang baru lahir. Dorongan dan perhatian anggota keluarga lainnya merupakkan dorongan positif untuk ibu (Suherini, 2009).

Upaya yang harus dilakukan dari tenaga medis khususnya bidan dan perawat untuk dapat membantu ibu mengatasi ketidaknyamanan dan memberikan intervensi agar ibu merasa lebih nyaman sehingga ASI dapat keluar dengan lancar. Dunia Ilmu keperawatan,terdapat teknik komplementer terapi musik untuk menenangkan jiwa bagi orang yang mendengarkannya (Nurgiwiati, 2015)

Menurut penelitian Jayamala et al (2015) terapi musik merupakan terapi yang 
dapat meningkatkan produksi ASI dan dapat digunakan dalam berbagai bidang. Mekanisme terapi musik dapat mempengaruhi emosional positif pada vasoreaktifitas endotel yang harus tetap diidentifikasi, salah satunya yaitu endorfindan sekresi oksitosin. Mendengarkan musik dapat mestimulus hipotalamus, respon fisiologi dan rangsangan emosional. Terapi musik dapat mengurangi kecemasan pada ibu setelah melahirkan dan memperlancar produksi ASI.

Tabel 7 Perbedaan jumlah produksi ASI antar kelompok intervensi terapi pijat oksitosin dan musik klasik (mozart)

\begin{tabular}{llcc}
\hline Pengamatan & \multicolumn{1}{c}{ Kelompok } & Rerata & Pvalue \\
\hline \multirow{4}{*}{ Pre test } & Pijat oksitosin & 53,59 & \\
& $\begin{array}{l}\text { Terapi musik } \\
\text { klasik (mozart) }\end{array}$ & 54,35 & 0,742 \\
& Pijat oksitosin & & \\
Post test & Terapi musik & 119,53 & 0 \\
& klasik (mozart) & 107,76 & 0,027 \\
\hline
\end{tabular}

Hasil uji Mann Whitney Test pretest diperoleh dengan nilai signifikansi ( $p$-value) 0,742 disimpulkan tidak terdapat perbedaan produksi ASI sebelum pemberian pijat oksitosin dan pemberian terapi musik klasik (mozart).

Hasil uji Mann Whitney Test posttest diperoleh dengan nilai signifikansi ( $p$-value) 0,027sehingga disimpulkan terdapat perbedaan produksi ASI sesudah perlakuan antara kelompok pijat oksitosin dan kelompok terapi musik klasik (mozart). Hasil penelitian ini didukung oleh Sulistyorini et al (2016) yang menyimpulkan adanya pengaruh pemberian terapi musik klasik (Mozart) terhadap inisiasi menyusui, durasi menyusui, dan volume ASI pada ibu menyusui. Memperdengarkan musik klasik (mozart) secara teratur semenjak kehamilan dapa memberikan banyak efek positif yaitu orang tu dapat berkomunikasi dan bersambung rasa dengan anak selama didalam kandungan, merangsang pertumbuhan otak anak dan motoriknya.

Tabel 8 Besar perbedaan selisih produksi ASI kelompok Pijat oksitosin dan kelompok Terapi musik klasik (mozart)

\begin{tabular}{lll}
\hline \multicolumn{1}{c}{ Kelompok } & \multicolumn{1}{c}{ Rerata } & Pvalue \\
\hline Pijat oksitosin & 65,91 & \\
Terapi musik klasik (mozart) & 53,41 & 0,011 \\
\hline
\end{tabular}

Hasil uji Mann Whitney Test diperoleh dengan nilai signifikansi ( $p$-value) 0,011 sehingga disimpulkan terdapat perbedaan selisih produksi ASI perlakuan antara kelompok pijat oksitosin dan kelompok terapi musik klasik (mozart). Kesimpulan bahwa pemberian pijat oksitosin lebih efektif dalam meningkatkan produksi ASI dibandingkan dengan terapi musik klasik (Mozart).

Air Susu Ibu (ASI) merupakan makanan dengan kandungan gizi terbaik sesuai dengan 
kebutuhan anak untuk dapat tumbuh dan berkembang secara optimal. Modal dasar pembentukan manusia berkualitas dimulai sejak dalam kandungan disertai dengan pemberian ASI ekslusif sampai anak berusia 6 bulan dan dilanjutkan hingga anak berusia 2 tahun. Masa ini adalah masa golden period (0-5 tahun) dimana kemampuan anak dalam menyerap informasi sangatlah tinggi (Kosim, 2009).

Ketidakmampuan menyusui membuat ibu post partum semakin merasa tidak percaya diri dan cemas. Kondisi ini bila tidak ditangani akan membuat ibu stress dan produksi ASI akan semakin berkurang. Upaya yang lain yaitu dari tenaga medis khususnya bidan dan perawat untuk dapat membantu ibu mengatasi ketidaknyamanan dan memberikan intervensi agar ibu merasa lebih nyaman sehingga ASI dapat keluar dengan lancar.

Dunia ilmu keperawatan, terdapat teknik komplementer terapi musik untuk menenangkan jiwa bagiorang yang mendengarkannya.Penelitian yang dilakukan pada sapi membuktikan bahwa sapi yang mendengarkan musik sambil diperas air susunya akan menghasilkan volume air susu yang lebih banyak dibandingkan dengan sapi yang diperah susunya tidak diperdengarkan musik. Perubahan kondisi ini merangsang pengeluaran hormone prolaktin (Vianna, 2011).

Teknik relaksasi lain yang dapat digunakan adalah pijat oksitosin yakni pemijatan tulang belakang pada nervus ke 5-6 sampai ke scapula yang akan mempercepat kerja otot syaraf parasimpatis yang merangsang hipofise posterior, sehingga produksi ASI menjadi lancar. Hasil penelitian membuktikan bahwa terdapat hubungan saat dimulainya seorang ibu mulai menyusui bayinya setelah partus dengan kelelahan ibu akibat partus, peningkatan hormon stres dan penurunan frekuensi pemberian ASI. Pemijatan oksitosin diharapkan mampu merangsang pengeluaran hormon prolaktin (Sari, 2017).

\section{SIMPULAN DAN SARAN}

Terdapat perbedaan jumlah produksi antar kelompok yang diberikan tindakan pijat oksitosin dengan kelompok yang diberi tindakan terapi musik klasik (mozart), dimana produksi ASI sesudah pemberian terapi pijat oksitosin lebih tinggi dibandingkan produksi ASI sesudah pemberian terapi musik klasik (Mozart). Perlunya menambah variable dalam penelitian ini untuk mengembangkan bentuk kepedulian terhadap pemberian ASI . 


\section{DAFTAR PUSTAKA}

Azizah, I., dan Yulinda, D. 2017. Pengaruh Pijat Oksitosin Terhadap Pengeluaran ASI Pada Ibu Postpartum Di BPM Pipin Heriyanti Yogyakarta. Jurnal Media Ilmu Kesehatan 6(1): 71-75.

Azriani, D., dan Handayani, S. 2016. The Effect Of Oxytocin Massage On Breast Milk Production. Journal Of Dama International Researchers (DIJR) 1(8): 47-50.

Dewi, R. 2016. Efektifitas Pemberian Terapi Musik Klasik (Mozart) Terhadap Produksi Air Susu Ibu (ASI). Jurnal Kesehatan Masyarakat 10(2): 78-85.

Guyton, H. 2007. Fisiologi kedokteran: Buku Ajar. EGC. Jakarta.

Hamranani, S. S. T. 2011. Pengaruh Pijat Oksitosin Terhadap Involusi Uterus Pada Ibu Post Partum Dengan Persalinan Lama Di Rumah Sakit Wilayah Kabupaten Klaten. Jurnal Ilmu Kesehatan 6(12).

Indriyani, D., Asmuji., dan Wahyuni, S. 2016. Edukasi Postnatal: Pendekatan Family Centered Maternity. Trans Medika. Yogyakarta.

Jannah, N. 2011. Asuhan Kebidanan Ibu Nifas. Ar-Ruzz. Yogyakarta.

Jayamala, AK., Lakshmanagowda, P. B., Pradeep, G. C. M., dan Gotoro, J. 2015. Impact Of Music Therapy On Breast Milk Secretion In Mothers Of Premature Newborns. Journal Of Clinical And Diagnostic Research 9 (4): 04-06.

Kosim, M. S. 2009. Buku Ajar Neonatologi. IDAI. Jakarta.

Manurung,S., Lestari, L. R., Suryati, B., Miradwiyana, B., Karma, A dan Paulina, K. 2011. Efektivitas Terapi Musik Terhadap Pencegahan Postpartum Blues Pada Ibu Primipara Di Ruang Kebidanan RSUP Cipto Mangunkusumo Jakarta Pusat. Jurnal Buletin Penelitian Sistem Kesehatan 14(1): 17-23.

Nurgiwiati, E. 2015. Terapi Alternatif dan Komplementer dalam Bidang Keperawatan. In Media. Bogor.

Nurliawati, E. 2010. Faktor-Faktor Yang Berhubungan Dengan Produksi Air Susu Ibu Pada Ibu Pasca Seksio Sesarea Di Wilayah Kota Dan Kabpaten Tasikmalaya. Tesis. Universitas Indonesia. Jakarta

198 Peningkatan Produksi Asi Ibu Menyusui Pasca .... 
Nutrisi Bangsa. 2013. Faktor Yang Mempengaruhi Produksi ASI. Sari Husada, < http://www. sarihusada.co.id/Nutrisi-Untuk-Bangsa/Kehamilan-dan-Menyusui/Menyusui/Faktor-YangMempengaruhi-Lancarnya-ASI. >. Diakses 02 Juli 2018.

Rahayu, D., Santoso, B., dan Yunitasari, E. 2015. Produksi ASI Ibu Dengan Intervensi Acupresure Point For Lactation Dan Pijat Oksitosin. Jurnal Ners 10(1): 9-19.

Roesli, U. 2010. Bayi Sehat Berkat ASI Ekslusif. Elex Media Komputindo.Jakarta

Soetjiningsih. 2013. Seri Gizi Klinik ASI Petunjuk untuk Tenaga Kesehatan. EGC. Jakarta..

Sriyati., dan Sari, Y. K. 2015. Pengaruh Pijat Punggung Terhadap Produksi ASI Ibu Post Partum Di Ruang Cempaka RSUD Ngudi Waluyo Wlingi. Jurnal Ners dan Kebidanan 2(2): 141-149.

Suherini.2009. Buku Ajar Asuhan Kebidanan Nifas Normal. EGC. Jakarta.

Sulistyoningsih, H. 2011. Gizi Untuk Ibu dan Anak. Graha Ilmu. Yogyakarta.

Sulistyorini, E., Anies., Julianti, H. P., dan Setiani, O. 2014. Efektifitas Terapi Musik Klasik (Mozart) TerhadapWaktu Keberhasilan Inisiasi Menyusu Dini Dan DurasiMenyusu Bayi. Jurnal Kebidanan Indonesia 5(2): 69-78.

Vianna, M. N,. Barbosa, A. P., Carvalbaes., Curba, A. J. 2011. Music therapy May Increase Breastfeeding Rates Among Mothers of Premature Newborn: a Randomized controlled trrial. Journal Pediatr (Rio J) 2011: 87(3) : 206-212. 